\title{
An Assessment of the Relationship Between Part-Time Instructors and Performance of University Graduates in Kenya's Economy: Effects of Salary Payments
}

\author{
Grace Akinyi Musa
}

\begin{abstract}
In Kenya, Universities are divided into two categories; Public and private Universities. Finances of these Universities come from various sources such as fees received from modules one and two students, capitalization from the government, cash received from international and local organizations such as grants and monies generated by the Universities. Research has shown that despite receiving these monies from different sources, most Universities in Kenya have been submerged into financial crisis. This ranges from nonpayment of Part-time Instructors' salaries and non-payment of full time Instructors extra income for hours worked above the required time, among other factors. These facts notwithstanding, it has been observed that in Kenya's Universities, the average ratio of Part-time Instructors to full time Instructors is $2: 1$ at a minimum. This implies that the Part-time Instructors input are of significance to the students' final output and Kenya's economy performance as well. It is expected that when Part-time Instructors are not rewarded for services rendered by them, the end result would translate into low quality graduates. This would not only affect the Universities standards but the graduates' performance in the business world hence lowering the general education standard of the whole economy. The general objective of the study was an assessment of the relationship between Part-time Instructors and performance of Universities graduates in Kenya's economy. The study applied the Theory of 'A bird in Hand' based on the fact that money loses value and therefore Instructors are interested in their cash returns at the earliest opportunity possible. A cross sectional research design was adopted since data was collected once within a short period. Total population comprised of Twelve Kenyan Universities and twelve employment organizations from all regions of Kenya. The study applied a stratified random technique to select the despondences. The null hypothesis was tested at $5 \%$ level of significance. Findings of the study revealed a positive significant relationship between Part-time Instructors and performance of Universities graduates in the Kenyan economy. The study established that non-payment of salaries, poor working conditions and all contributed towards the production of half-baked graduates who could not match the industry requirements.
\end{abstract}

Index Terms-Performance of Kenya's Universities Graduates, Payment of Salaries, A Bird in Hand Theory

\section{INTRODUCTION}

\section{A. Background of the Study}

Kenya is looking forward to achieving Vision 2030 starting with the big four agenda in terms of developing its economy $(\mathrm{GoK}, 2010)$. These would include reinforcement

Published on April 02, 2020.

G. A. Musa, School of Business and Management Studies, Department of Accounting and Finance, Technical University of Kenya, Kenya.

(e-mail: gracemusa147@gmail.com) of food security, affordable housing, investment in manufacturing sectors and affordable healthcare for all. Achievement of these would be witnessed on the creation of jobs which would enable Kenyans meet their basic needs hence lowering the cost of living. However, this dream may not be achievable in the Kenyan economy. This has partly been attributed to the financial crisis witnessed in most of Kenya's Universities whereby Part-time Instructors have been the hardest hit. Research shows that most public Universities in Kenya have employed more support staff than instructors.

Thus more funds are used to pay these groups of workers at the expense of the Part-time Instructors who end up not being paid their salaries for a long time despite rendering the educational services (Cyrus Nyakundi, 2019).

These facts notwithstanding, it has been observed that in Kenya's Universities, the ratio of Part- time Instructors to full time Instructors is $2: 1$ at the minimum. The high ratio of part- time Instructors has been attributed partly to the financial crisis which most of these Universities find themselves in. The multiplier effects have been twofold; first in most of these Universities the unpaid Part- time Instructors have taken off with students' scripts in the hope that they will be recalled and paid their dues (JKUAT, 2018). As a result, most students have taken longer periods than expected to graduate since they have missing marks. Secondly, most of these students are given raw deals since an 'angry and hungry' Instructor is not expected to give quality material.

Consequently, most students who graduate from Kenya's Universities end up as 'half-baked' graduates (Demagalhaes \& Lisa, 2011). This has resulted into most organizations employing persons with lower qualifications to undertake graduate work (World Bank \& IMF, 2017). This scenario has created a mismatch between skills posed by most fresh Universities graduates and employers requirements on entry into the job market (Borges, Santos, \& Leal, 2014);(Kavangah \& Drennan, 2008). The repercussions are felt not only by the business world, but also in the Kenyan economy as well which is looking forward to achieving Kenya Vision 2030 through the big 4 agenda.

\section{B. Statement of the Problem}

There have been numerous complaints by many authors, Federation for Kenya Employers (FKE) and the Commission for University Education (CUE) who have constantly pointed out that the quality of University education in Kenya had gone down. Thus pointingout to a possibly of the production of 'half baked' graduates from most of Kenya's Universities, emanating possibly, from the 
non-payment of salaries to the Part- time Instructors in Kenya's Universities. Most Universities have given more emphasis to building of infrastructure. This has resulted into funds being diverted into private activities than skills development.

The multiplier effects have been witnessed in lack of money not only for skills development but also payment of Part-time Instructors' salary. Part-time Instructors are the most exploited calibre in Kenya's Universities. They are voiceless, invisible and lonely in their hectic lives lecturing at the Universities. Analysis records from the Finance Departments of various Kenya's public Universities show that they do not honour their obligations for the payment of salaries to Part-time Instructors. Payments of salaries to Part-time Instructors in most of these Universities not only take a long time but they are also underpaid. For instance, according to statistical report from most Kenyan Universities a Part-time Instructor is paid kshs 49,000 only for lecturing an undergraduate course per semester. This amounts to Kshs 34,400 after a tax which translates to Kshs 8,600 per month and the amount is paid at earliest after 3 months or not paid at all. This situation has created multiplier effects on the performance of Kenya's Universities graduates, the University students and the business world at large.

A study by (Shattock, 2007) established that there was a problem with the University teaching since the skills posed by the University graduates did not measure to employers' threshold. Similar sentiments were shared by (Kavangah \& Drennan, 2008), the study established that there was a mismatch between skills posed by fresh graduates on entry into the job market with employers' expectations. These findings were further supported by a report from the World Bank and International Monetary Fund (2017), which stated that most organizations in Kenya employed University graduates who were 'half-baked.'

The necessity of this study was conditioned by;

$>$ Non-payment of salaries to Part-time Instructors' in most of Kenya's Universities.

$>$ Financial crisis facing Kenya's Universities.

$>$ Meeting the requirements of Kenya's Vision 2030 through the Big 4 agenda.

The big question the current study sought to answer was whether there existed any relationship between Part- time Instructors and Performance of Universities graduates in the Kenyan economy.

\section{Objectives}

\section{1) General Objective}

The general objective of the study was an assessment of the relationship between Part-time Instructors and Performance of Universities graduates in the Kenyan economy.

\section{2) Specific Objectives}

1. The study evaluated the relationship between Parttime instructors and performance of Universities graduates in the Kenyan economy.

2. The study analysed the moderating effect of salary payments on the relationship between Part-time instructors and performance of Universities graduates in the Kenyan economy.

\section{Hypotheses}

The study hypotheses were:

$\mathrm{H}_{01}$ : There was no positive significant relationship between Part-time Instructors and performance of public Universities graduates in the Kenyan economy.

$\mathrm{H}_{02}$ : There was no positive significant moderating effect of salary payments on the relationship between Parttime instructors and performance of Universities graduates in the Kenyan economy.

\section{E. Significance of the Study}

The results of the study will enable; Kenya's Universities appreciate the important roles played by Part -time Instructors when paid their salaries adequately in moulding the Universities graduates. It is expected that this will; equip the students with the skills and knowledge required in the workplace; Give valuable information to Universities management to know how they can generate money from module II students and internally to ensure prompt payments of Par-time Instructors salaries to improve their output and hence producing effective and efficient graduates' to the business world. They should also ensure that only required numbers of Part -time are employed which the Universities are able to pay promptly. Other Researchers will benefit as this study will act as a reference point in their studies and they will be expected to conduct research in areas the study will not have covered in terms of conceptual, contextual, methodological and theoretical limitations.

\section{LITERATURE REVIEW}

\section{A. Theoretical review}

The current studyapplied The 'Bird in Hand' Theory coined by Myron Gordon (1963) and John Litner (1964) (Alzomaia \& Al-Khadhiri, 2013). The theory states that investors prefer the certainty of dividend payments to the possibility of substantially higher future capital gains. The theory was important to the study, given that Part-time Instructors would wish to be paid their salaries in the earliest opportunity possible. This theory thus informed the study's variables.

A theoretical gap was witnessed whereby other related studies applied different theories. For instance,(Riechi, 2012)on examining the financing of public universities in Kenya given the changing socio-economic and policy environment applied the use of human capital theory, initially developed by T. Schultz in the late 1950's (Schultz, 1961)and further developed by G.S. Becker (Becker, 1975), and the theory of public expenditures articulated by (Musgrave \& Musgrave, 1989).

\section{B. Empirical review}

Numerous studies have been conducted with respect to Part time lecturers in most countries across the world including; (Wambui, Ngari, \& Waititu, Teaching Experience of Part-time Lecturers affect the quality of University Education inPublic Universities in Kenya, 2016), the study aimed at establishing the effect of teaching experience of part time lecturers on the quality of University education in the public Universities in Kenya. The study established a 
positive relationship between predictor variable and outcome variable with a major finding that many part time lecturers had many years of teaching experience.

A study by (Wambui, 2018), reported conflicting findings with respect to part time years of teaching experience. The study aimed at establishing the influence of outsourcing adjunct faculty on students' satisfaction in public Universities in Kenya. The study established that: there was a medium positive relationship between competency, role profile, work ethics and students' satisfaction; a moderating effect between outsourced adjunct faculties and working conditions. The study observed that the adjunct faculty had the required competencies to teach in institutions of higher learning; however, they lacked teaching skills and effective communication skills.

A USA study by (Smith, 2010)assessed the impact of Part time faculty on student retention. Statistical results from logistic regression analysis predicted the likelihood of decrease in first time full time student retention with increased exposure to part-time faculty to the next semester with all academic years combined.

Another USA study conducted by (Cashwell, 2009)assessed factors that affected Part time job satisfaction in the Colorado Community College system. Findings revealed that part time members were very dissatisfied with the benefits and healthcare coverage. They were slightly satisfied with their part time jobs in the college. This finding was similar to a study by (Kyule, Kangu, Wambua, Bernadette, \& Kamau, 2014)assessed the effect of part time lecturers on University education in Kenya based on cost strategy. The study found that most Universities employed part time faculty as a cost cutting strategy. It was further established that most part time lecturers were not satisfied with their jobs and therefore were not adequately motivated and lacked commitment in their work. This negativity affected their service deliveries.

A study carried out by (Riechi, 2012), examined the financing of public universities in Kenya given the changing socio-economic and policy environment. Findings revealed that the main problems facing Part -time Instructors were low or non- payment of salaries after longer durations of time (Riechi, 2012).

Numerous studies have been conducted with respect to part time lecturers in most countries across the world without any universal agreement. Further most of the studies focused mainly on the' ill treatment' accorded to the part time lectures which made them unsatisfied. The studies did not dig further into the effects, non-payments of salary to Part-time Instructors had on performance of Universities graduates on the growth of Kenya's economy. The current study has come in handy to bridge the void created, hence justification of the study.

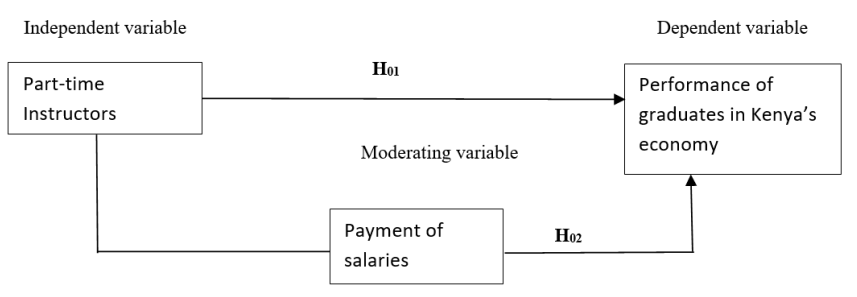

Fig. 1. Conceptual Framework: Source Author (2020)

$\mathrm{Ho}_{1}$ and $\mathrm{Ho}_{2}$ depict direct relationship and moderating relationship respectively.

\section{Methodology of The Study}

The study applied cross sectional research design since data was collected at once within a short period. Total population comprised

of Part-time Instructors from twelve Kenya's Universities and twelve organizations in Kenya. The study applied stratified random sampling technique to obtain its despondences'. The model applied was regression logistic method since the outcome was binary and dichotomous in nature of either Part- time Instructors paid their monthly salaries or not, each having effects on Universities graduates performance in the Kenyan economy.

\section{DATA ANALYSIS}

TABLE I: MODEL SUMMARIES OF PART-TIME INSTRUCTORS AND PERFORMANCE OF GRADUATES IN THE KENYAN ECONOMY

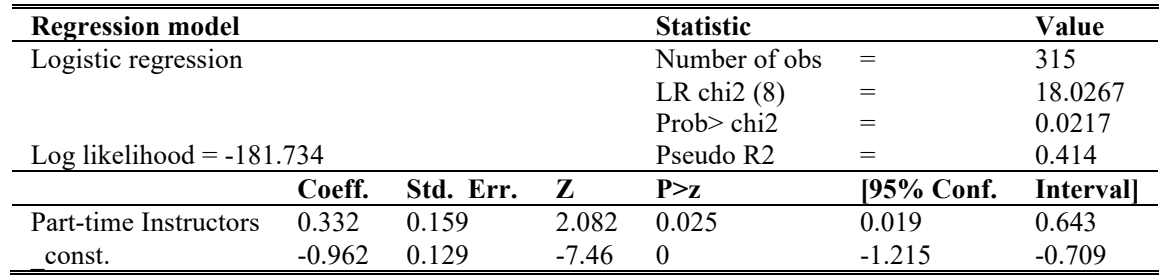

The summary statistics is divided into two sections: the goodness of fit section and the coefficient section. In the goodness-of-fit part, we see LR Chi2 $=18.0267$ with a pvalue of 0.0217 . Chi2 value and its p-value are used to check for the significance of the model fit. Since the pvalue is less than 0.05 , the Chi2 value implies that the model is significant and adequately fits the data. That is, the model is a significant fit than a model with no predictor(s), an empty model.

The Pseudo R2 value is used to check for the extent to which the independent variable(s) influences the dependent variable. Therefore, the value of the Pseudo $\mathrm{R} 2=0.414$ implies that variations in the independent variable (PartTime Instructors) only account for $41.4 \%$ of the total variations in the log likelihood of performance of a graduate in the Kenyan Economy. This means that the remaining $58.6 \%$ of the variation is accounted for by factors not explained by or included in the model.

In the coefficient section, we have coefficients for each of the predictor variables with the corresponding standard 
errors, z-statistics, p-values and the 95\% confidence intervals. Summary statistics for this section shows that the coefficient of Part-time Instructors was 0.331, and that of the constant coefficient was -0.962 . Based on these coefficient values, we obtained the following logistic regression equation

$$
\log _{e}\left(\frac{P(Y)}{1-P(Y)}\right)=-0.951+0.332 X
$$

To test for the effect of Part-time Instructors, of importance is the coefficient value for Part-time Instructors. From Table, the $\mathrm{Z}$ statistic of the coefficient of Part-time Instructors was found to be 2.082 with a corresponding pvalue $0.025(<0.05)$. Based on the obtained p-value, the coefficient was considered to be significant at 0.05 level of significance.
This means that any improvement in the aspects of Parttime Instructors by one unit would increase the log odds of a graduate performing in the Kenyan economy, by 0.332 . From the coefficient of Part-time Instructors, the odds ratio of performing in the job market corresponds to a unit increase in the level of Part-time Instructors which is given by $e^{0.332}=1.394$.

Since the p-value was less than 0.05 , we inferred that there is a significant proportional change in the odds of a graduate performing by 1.392 due to a unit increase in the levels of Part-time Instructors. Since the p-value is less than 0.05 , the study rejected the null hypothesis $\mathrm{H}_{01}$ at $5 \%$ level of significance about the non-significance of the effect of Part-time Instructors on the performance of graduates in the Kenyan economy. This decision implied that Part-time Instructors have a significant influence on the performance of a graduate in the Kenyan economy.

TABLE II: MODEl SUMMARY FOR MODERATING EFFECT OF PAYMENT OF SALARIES

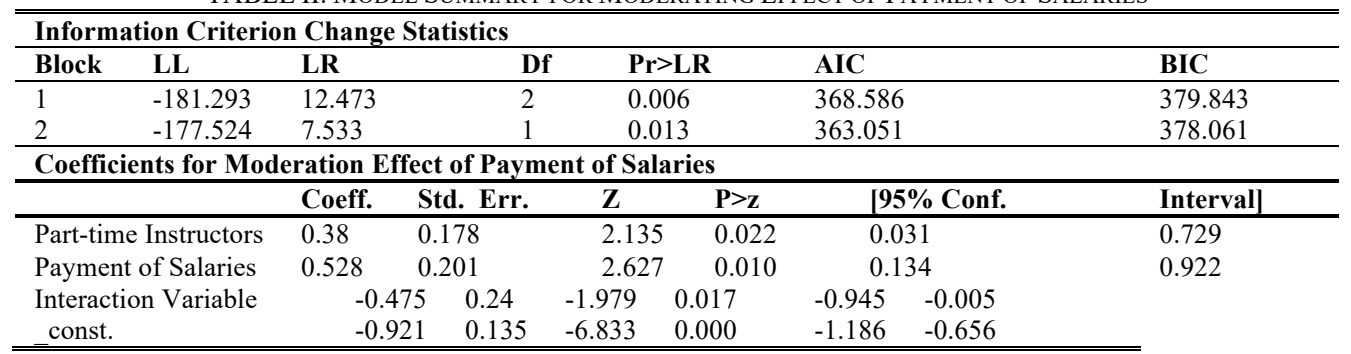

In the Table, the study has the likelihood ratio change due to the addition of the interaction variable. Significance of this change is tested by the p-value in the Block 2 model.

From the table, the study observed that the change in the LR due to the addition of the interaction variable is significant as shown by the P-value $(=0.013)$, which is less than 0.05 .

This confirmed that the addition of the interaction variable significantly improved the model at 5\% significance level. In the coefficients' section, we have the coefficients for Part-time Instructors, Payment of Salaries and the interaction variable. Both Part-time Instructors and Payment of Salaries were significant since their respective p-values, 0.022 and 0.010 , were significant at $5 \%$ level of significance. Of interest was, however, the significance of the added interaction variable.

From the output, the study observed that the interaction variables were significant at 5\% significance level since the corresponding $\mathrm{p}$-value $=0.017$ was less than 0.05 .

Based on the significances of the both likelihood ratio change and the interaction variable, the study rejected the null hypothesis $\mathrm{H}_{02}$. Payment of Salaries had no significant moderating effect on the relationship between Part-time Instructors and graduate performance in the Kenyan economy. The study therefore, concluded that Payment of Salaries had a significant moderating effect on the relationship between Part-time Instructors and graduate performance in the Kenyan economy.

\section{Findings OF THE STUdY}

First, the study established that there was a positive significant relationship between Part-time Instructors and performance of public Universities graduates in Kenya's economy.

Secondly, the study established that there was a positive significant moderating effect of salary payments on the relationship between Part-time instructors and performance of Universities graduates in Kenya's economy.

This finding is similar to a study carried out by (Shattock, 2007) which revealed that graduates from Universities were not 'work-ready'. This is justified as majority of these graduates as already established by the current study were by Part-time Instructors.

Similar views were shared by a report from (World Bank \& IMF, 2017) which stated that most organizational across the world were employing 'half- baked' graduates to undertake most jobs in their economies. These are the effects of Part-time Instructors. A study by (Kavangah \& Drennan, 2008), established that there was a mismatch between employers expectations and skills posed by graduates on entry into the job market

These findings were based on the following facts; in Kenya Universities, most Part-time Lecturers were not paid their salaries promptly; some were underpaid while others were not paid at all. This compromised on the quality of graduates produced. Consequently, creating a mismatch between skills posed by fresh graduates on entry into the job market and employers requirements.

Further, working conditions were not conducive to most Part-time lecturers; they lacked where to sit while preparing for their lessons; were looked down upon by full time Lecturers; given units which full time lecturers were not comfortable with or those with large populace such as common units; contracted to teach and even mark for full time Lecturers at meagre tokens. The study found out that 
the quality of education in Kenya Universities has been adversely affected and this has been transferred to the economy at large.

However, a few Universities in Kenya such as Strathmore, United States International University and KCA Universities who $\mathrm{p}$ ay their Part-time Instructors salaries on a monthly basis at a good rate produce high calibre graduates. Employers' responses confirmed that they find graduates from these Universities efficient and effective than their counterparts from other Universities.

\section{Limitations OF THE STUDY}

Contextually, the study was carried out in the selected twelve Kenya's Universities. However, the study could have been undertaken in all Kenya's Universities to give a complete picture of the treatment of part-time Instructors in all Kenya's Universities.

Conceptually; the study could have used other variables such as full time Instructors.

Theoretically; the study could have used other dividend theories such as signalling theory, ownership theories, among others.

Methodologically; the study could have used a longitudinal research design which is collected after a long period of time. However, despite these limitations, the quality of the research was not compromised.

\section{RECOMMENDATIONS OF THE STUDY}

The Government of Kenya and universities authorities should: Ensure that pressures in favour of revenue generation do not accumulate to the point where they can distract Part- time Instructors from their main mission of lecturing and research; Embark on revenue generating activities to raise more income and pay Part-time Instructors salaries; Employ Part-time on a First in First Employed basis and based on performance to encourage quality output.

Much as it is important to employ non-teaching staff in the Universities, priority should be given to the employment of full time staff as they are the main stream in the Universities. The high enrolment rate in Kenyan Universities further justifies the employment of more Instructors in proportion to the increase in the number of Universities students. This will increase the quality of Universities graduate and hence bridge the mismatch that has been experienced in the business world.

\section{RECOMMENDATIONS FOR FUTURE RESEARCHERS}

Future studies should;

- Be undertaken in all Kenya's Universities to give a complete picture of the treatment of part-time Instructors in all Kenya's Universities.

- Use other variables such as full time Instructors.

- Apply other dividend theories such as signalling theory, ownership theories, among others.

- Use a longitudinal research design which is collected after a long period of time.

\section{CONClusion OF ThE STUdy}

One of the main pillars for economic development of any economy is to improve its education sector. Kenya has devolved its government and is looking forward to achieving Kenya Vision 2030. Realization of this goal calls for a complete overhaul in the Kenya's educational system. This starts with improving the standards of living of Parttime Instructors who are a majority of most Kenya's Universities Teaching fraternity.

\section{ACKNOWLEDGMENT}

I wish to thank my dear parents, Musa Agina and Judith Musa for their encouragement and prayers and who's early counselling and guidance instilled confidence in me to believe in myself. This paper would not have been successfully completed without the love, support and sacrifices of my husband, Amos Akelo, my daughters: Lucy, Judy, Sandra, Sally and my son, Edward throughout the entire process. I also thank the Editing Team of EJBMR and their peer review Team who have worked hand in hand with me. Their through corrections and support has enabled me come up with this perfect paper. May the Almighty Father bless you all. Amen.

\section{REFERENCES}

Alzomaia, T., \& Al-Khadhiri, A. (2013). Determination of Dividend Policy: The Evidence from Saudi Arabia. International Journal of Business and Social Science, 181-192.

Becker, G. S. (1975). Human Capital: A Theoretical and Empirical Analysis with Special Reference to Education. (G. S. Becker, Ed.) New York: National Bureau of Economic Research.

Borges, L. F., Santos, C. K., \& Leal, E. A. (2014). Quality in Educational Service: Expectations Versus Performance in the Accountinh Undergraduate Course. Europen Scientufic Journal, 10(1), 100-114.

Cashwell, A. (2009). Factors affecting Part-time faculty job satisfaction in the Colorado Community college system . Dissertation: Colorado State University.

Demagalhaes, R. W., \& Lisa, R. (2011). Factors Affecting Accounting Students' Employment Choices: A Comparison of Students' and Practitioners' Views. Britain: Publishers.

GoK. (2007). Kenya Vision 2030.The popular version. Nairobi: Ministry of State for planning, National Development and vision 2030.

Kavangah, M., \& Drennan, L. (2008). What Skills and Attributes Does an Accounting Graduate Need? Evidence From Students' Perceptions and Employer Expectations.Accounting Finance (Vol. 48).

Kyule, A., Kangu, M., Wambua, P., Bernadette, M., \& Kamau, S. (2014). Strategizing on cost:Effect of part time lecturers on university education in Kenya. Prime Journal of Social Science, 603-607.

Musgrave, R., \& Musgrave, P. (1989). Public Finance in theory and practice (Fifth ed.). New York: McGraw-Hill Book Co.

Riechi, A. (2012). Revenue diversification in Kenya's public universities and implications for efficiency and equity: an analysis of educational finance in the African context. Phd Thesis.

Schultz, T. W. (1961). Investment in Human Capital. The American Economic Review, 51, 1-17.

Shattock, M. (2007). Higher Education Management and Policy. Journal of the Programme, 19(2).

Smith, C. (2010). The Impact of Part-time faculty on student retention:Acase study in Higher Education. A dissertation in Urban Leadership and Policy Studies in Education and Social Science.

Wambui, T. (2018). Influence of outsourcing adjunct faculty on student's satisfacction in Public Universities in Kenya. Phd Thesis.

Wambui, T., Ngari, D. J., \& Waititu, D. A. (2016). Teaching Experience of Part-time Lecturers affect the quality of University Education inPublic Universities in Kenya. European Journal of Research and Reflection in Educational Sciences, 4(6), 1-19. 


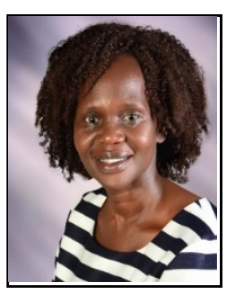

Dr. Grace Akinyi Musa, Lecturer Department of Accounting \& Finance, School of Business and Management Studies of the Technical University of Kenya

Bachelor of Education (Business Studies and Economics) - University of Nairobi- 1992

Masters of Business Administration - Kenyatta University-2008

Title of Project 'Factors affecting the Distribution of Cash Dividends in Manufacturing Firms Quoted at the Nairobi Security Exchange in Kenya'

Doctor of Philosophy in Business Administration-The Technical University of Kenya-2019

Title of Thesis 'an Empirical Assessment of the Relationship between Introductory Accounting Course and Choice of Accounting Major: Effects of Students Performance and Career Guidance'

Work Experience:

a. Lecturer in the department of Accounting and Finance TU-K

b. Chair Person in the Department of Accounting and Finance (20092018)

c. Lecturing undergraduates and post graduate students in all Accounting and Finance Units,

d. Supervision of students' projects and Industrial Based Learning

Achievements: Spearheaded the development and reviews of the following Curricula / Study Manuals

a. Bachelors of Commerce syllabus; Bachelors of Science in Accountancy syllabus and Diploma in Accountancy syllabus at the Technical University of Kenya.

b. Prepared two Study Manuals for Cost Accounting and Advanced Financial Accounting for Distance Learning students at the KCAUniversity (Kenya)

\section{Published in Internationally Peer Review Journals}

a. Grace Akinyi Musa1, Evans Vidija Sagwa2, Selfano Odoyo3, Headmound Okari'4 Moderating Effect of Career Guidance on the Relationship between Introductory Accounting Course and Students' Choice of Accounting as a Major in Kenyan Universities. 'European Journal of Business and Management, vol.10, no.11, pp. 125.

b. Grace Akinyi Musa1, Atieno A. Ndede-Amadi2, Evans Vidija Sagwa,3 Selfano Odoyo.4 'Assessing The Influence of Introductory Accounting Course Teaching Methodology on Students' Choice of Accounting Major in Kenyan Universities.' Research Journal of Finance and Accountingvol.9, no.7, pp.168.

c. Grace Akinyi Musa1, Atieno Ndede Amadi2 'The Influence of Performance on students Choice of Accounting Major in Kenyan Universities.' Asia Pacific Journal of Research in Business Management, vol.9, no.3, pp.38-53. 